\title{
Fate of trypsin and chymotrypsin in the human small intestine
}

\author{
D. M. GOLDBERG, ${ }^{1}$ R. CAMPBELL, AND A. D. ROY \\ From the University Departments of Surgery and Pathological Biochemistry, \\ Western Infirmary, Glasgow
}

The present consensus regarding the fate of the pancreatic proteases trypsin and chymotrypsin in the human intestinal tract rests largely upon experiments by Borgström, Dahlqvist, Lundh, and Sjövall (1957), who measured their activity in juice obtained by intubation of the small intestine. The results indicated a progressive fall in activity from the pylorus towards the ileocaecal valve. Support for their conclusion that enzyme degradation takes place in the small intestine has come from Pelot and Grossman (1962), who demonstrated rapid inactivation of pancreatic enzymes in the rat.

Studies in this laboratory have shown binding of trypsin and chymotrypsin to human intestinal cells (Goldberg, Campbell, and Roy, 1968a), and have demonstrated that the spectrophotometric assay of Lundh (1957), as used by Borgström et al (1957), was incapable of estimating bound enzymes. An alternative possibility was that the enzymes became bound to the surface of cells during transit through the intestine and to components of intestinal debris. Measurement of the daily output of trypsin in subjects on ileal drainage (Roy, Campbell, and Goldberg, 1967) gave data which, when compared with the trypsin concentration of human pancreatic juice (Haverback, Dyce, Bundy, and Edmondson, 1960), suggested that most of the enzyme reached the terminal ileum intact.

It therefore seemed desirable to examine the fate of pancreatic enzymes in the human small intestine, considering all the factors that can interact with the enzymes from the point of their release into the duodenum. Such a study is the subject of the present report.

\section{MATERIALS AND METHODS}

The following materials were employed:-

ILEAL FLUID This was obtained from patients with an established ileostomy as previously described (Roy et al,

1Present address: Department of Chemical Pathology, The Royal Hospital, Sheffield, 1.
1967). Where output was quantitated the patients were on a controlled diet 24 hours before the start of the experiment, and this was continued throughout the collection period. Homogenates of the ileostomy contents were prepared in $0 \cdot 15 \mathrm{M} \mathrm{NaCl}$, and supernatants were separated after centrifugation at $45,000 \mathrm{~g}$ per minute. These steps, together with the titrimetric assay of trypsin and chymotrypsin by procedures slightly modified from those of Haverback, Dyce, Gutentag, and Montgomery (1963), have already been described (Roy et al, 1967).

PANCREATIC JUICE This was obtained during sphincterotomy on a subject with recurrent cholelithiasis. The pancreas was normal at operation. Juice was collected into ice from a cannula draining the pancreatic duct for a period of $30 \mathrm{~min}$ after injection of 90 units of pancreozymin (Boots Pure Drug Co. Ltd., Nottingham, England). This was activated by adding bovine pancreatic trypsin to a final concentration of $1 \mu \mathrm{g} / \mathrm{ml}$ and $\mathrm{CaCl}_{2}$ to a final concentration of $0.005 \mathrm{M}$. It was then incubated at $4^{\circ} \mathrm{C}$ until no further increase in trypsin or chymotrypsin activity took place (approximately 56 hours) after which it was divided into aliquots and stored at $-20^{\circ} \mathrm{C}$. We were unable to obtain any further samples of pancreatic juice during the period spanned by this investigation.

GASTRIC JUICE This was obtained following histamine stimulation in normal individuals. All samples were checked for the presence of acid and were filtered through gauze. Bile-stained samples were rejected.

BILE This was obtained from subjects on T-tube drainage after choledochotomy, and was cultured to ensure sterility and filtered through gauze.

INTESTINAL HOMOGENATES Sections of small intestine were obtained at several operations. These comprised gastrojejunostomy when a small sample of jejunum was obtained; resection of caecal carcinoma when a $12 \mathrm{~cm}$ section of terminal ileum was available; and resection of colonic neoplasm adherent to small bowel when variable lengths of small bowel segments were available. All the material was histologically normal.The sections were split longitudinally, washed four to six times with cold $0.25 \mathrm{M}$ sucrose until no more faecal material could be removed, clamped at the corners, and the mucosa was gently 
scraped with the back of a scalpel blade. It was found microscopically to consist almost exclusively of intestinal epithelium. Homogenization was carried out in cold 0.25 M sucrose using a motor-driven teflon pestle (Sireica, New York) until the cells, as gauged by light microscopy, had been adequately ruptured. Nitrogen was determined by a microKjeldahl procedure (Prunty, McSwiney, and Hawkins, 1959).

BACTERIA Cultures of $E$. coli and Bacteroides isolated from human ileal contents were harvested anaerobically on tryptone soya broth (Oxoid, London). The following organisms obtained from the Torry Research Institute, Aberdeen, Scotland, were also harvested as above: Streptococcus faecalis (775, strain Tissier), Clostridium sporogenes (8053, strain MCA 3679), Klebsiella aerogenes (418, type 1, strain 240), Proteus vulgaris (4175, strain Lehmann NCT 4175), Lactobacillis acidophilus (1723, strain Ruttger 4B, grown in milk medium), Staphylococcus aureus (6571, strain 3 R 7089).

Suspensions were made in $0 \cdot 15 \mathrm{M} \mathrm{NaCl}$, and aliquots ruptured under refrigeration using the Soniprobe type 1130 (Dawe Instruments, Acton, London) at 4.8 amps for three one-minute periods.

ENZYME SOLUTIONS The enzyme standards used in this work were: trypsin ex bovine pancreas, $2 \times$ crystallized, salt free; $\alpha$-chymotrypsin ex bovine pancreas, $3 \times$ crystallized, salt free, both from Koch-Light Laboratories, Colnbrook, Bucks, England. They were dissolved in $0.005 \mathrm{~N} \mathrm{HCl}, 0.005 \mathrm{M}$ with respect to $\mathrm{CaCl}_{2}$. We have found it necessary to add crystalline bovine serum albumin (British Drug Houses Ltd., Poole, Dorset, England) to the chymotrypsin standards in a final concentration of $1 \%(\mathrm{w} / \mathrm{v})$ to prevent loss of activity during storage at $-20^{\circ} \mathrm{C}$. These solutions were used in experiments on the behaviour of bovine enzymes. In the experiments on recovery from intestinal instillation, the enzymes were dialysed for 48 hours against frequent changes of distilled water at $4^{\circ} \mathrm{C}$ before being made up in $0.15 \mathrm{M} \mathrm{NaCl}$. Protein was precipitated during dialysis but did not affect the activity which was checked before and after administration to the patient.

\section{RESULTS}

EFFECT OF INTESTINAL SECRETIONS When solutions of crystalline enzymes were incubated at $37^{\circ} \mathrm{C}$ for two hours with human gastric juice, virtually all the

TABLE I

EFFECT OF INTESTINAL SECRETIONS ON BOVINE TRYPSIN AND CHYMOTRYPSIN ${ }^{1}$

\begin{tabular}{lrr} 
& \multicolumn{1}{c}{ Trypsin } & \multicolumn{1}{c}{ Chymotrypsin } \\
\hline Gastric juice & $7 \cdot 0 \pm 1 \cdot 7$ & $1 \cdot 1 \pm 0.7$ \\
N/10 HCl & $99.9 \pm 0.1$ & $62.1 \pm 1 \cdot 2$ \\
Bile & $95.8 \pm 1.7$ & $106.2 \pm 18.5$
\end{tabular}

${ }^{1}$ Mean $\pm \mathrm{SE}$ of four experiments. Equal volumes of test secretion and enzyme solutions $(1 \mathrm{mg} / \mathrm{ml})$ incubated at $37^{\circ} \mathrm{C}$ for two hours. Data as percentage of zero time control. trypsin and chymotrypsin activities were lost (Table I). One-third of the chymotrypsin and $15 \%$ of the trypsin failed to survive 15 minutes' incubation with gastric juice; $0.1 \mathrm{~N} \mathrm{HCl}$ was without effect on trypsin, but inactivated $38 \%$ of the chymotrypsin over a two-hour period. Bile was without pronounced effect on either enzyme.

EFFECT OF AUTOINCUBATION When homogenates of ileostomy contents were incubated at $37^{\circ} \mathrm{C}$, there was a steady decrease in chymotrypsin activity to $74 \%$ after six hours (Table II). A more rapid fall in trypsin activity took place under these conditions, but this seemed to level off so that at four and six hours after incubation about $37 \%$ of the original activity was lost.

\section{TABLE II}

EFFECT OF INCUBATION AT $37^{\circ} \mathrm{C}$ ON TRYPSIN AND CHYMOTRYPSIN ACTIVITIES OF HUMAN ILEAL HOMOGENATES ${ }^{1}$

\begin{tabular}{lll}
$\begin{array}{l}\text { Incubation } \\
\text { Time }(\text { hr })\end{array}$ & Trypsin & Chymotrypsin \\
\hline 2 & $83 \cdot 2 \pm 2 \cdot 9$ & $91 \cdot 3 \pm 3 \cdot 4$ \\
4 & $62 \cdot 6 \pm 2 \cdot 1$ & $83 \cdot 1 \pm 2 \cdot 9$ \\
6 & $62 \cdot 9 \pm 4 \cdot 0$ & $74 \cdot 0 \pm 6 \cdot 0$
\end{tabular}

${ }^{1}$ Mean \pm SE of four experiments. Data as percentage of zero time control.

EFFECT OF INTESTINAL CELL PREPARATIONS The addition of crystalline enzymes to homogenates of ileal (three samples) and jejunal (three samples) mucosa in the proportion of $10 \mu \mathrm{g}$ enzyme plus $2 \mathrm{mg}$ homogenate nitrogen per millilitre of mixture gave no immediate change in activity, indicating the absence of specific inhibitors. When these mixtures were incubated at $37^{\circ} \mathrm{C}$ for periods up to two hours, at the $p \mathrm{H}$ used for the enzyme determinations ( $p \mathrm{H} \mathrm{8.2,} \mathrm{trypsin;} p \mathrm{H} \mathrm{7.8,} \mathrm{chymotrypsin),} \mathrm{the}$ differences never exceeded the reproducibility of replicate analyses $( \pm 5 \%)$. Thiseliminates destruction by intracellular proteases and is in agreement with the very low proteolytic activity at neutral and alkaline $p \mathrm{H}$ previously found in intestinal cell preparations (Goldberg, McAllister, and Roy, 1967).

EFFECT OF NEOMYCIN The total daily output of trypsin and chymotrypsin was measured on three or four consecutive days in patients with ileal drainage. Neomycin sulphate, in a dose of $2 \mathrm{~g}$, qid, was then given. After 24 hours, daily measurements of the output of trypsin and chymotrypsin were made for the same number of days as previously, while neomycin therapy was continued. There was a fall of 5 to $10 \%$ in the chymotrypsin output in the homogenate and in the supernatant of the ileal 


\section{TABLE III}

AFFECT OF NEOMYCIN (8 G/DAY) ON OUTPUT OF TRYPSIN AND CHYMOTRYPSIN IN SUBJECTS ON ILEAL DRAINAGE ${ }^{1}$

\begin{tabular}{llclll} 
& \multicolumn{2}{l}{ Trypsin } & & \multicolumn{2}{l}{ Chymotrypsin } \\
\cline { 2 - 3 } \cline { 5 - 6 } \cline { 5 - 6 } & Homogenate & Supernatant & & Homogenate & Supernatant \\
\hline Control & $222 \pm 56$ & $143 \pm 26$ & & $354 \pm 63$ & $173 \pm 40$ \\
Test & $116 \pm 28$ & $80 \pm 17$ & & $321 \pm 61$ & $165 \pm 39$
\end{tabular}

'Data as mg per 24 hours, mean $\pm \mathrm{SE}$ for seven subjects. In four, test and control periods were four days; in three, test and control periods were three days.

drainage material after neomycin, but these changes were insignificant (Table III). By contrast, neomycin lowered the trypsin output in homogenate and supernatant by over $30 \%$. Analysis of the mean values for each subject before and after neomycin by the paired $t$ test showed these changes to be statistically significant (homogenate, $t_{o}=3.43$; $P<0.02 ;$ supernatant, $\left.t_{o}=2.94 ; \quad P<0.05\right)$. The distribution of each enzyme between the soluble and insoluble phases in ileal material was unaltered by neomycin. This is best expressed by considering the output in the supernatant as a percentage of that of the whole homogenate. The mean values before and after neomycin were trypsin $64.4 \%$ and $68.9 \%$; chymotrypsin $48.8 \%$ and $51.5 \%$.

EFFECT OF BACTERIA When mixtures were made containing in final concentration $20 \mu \mathrm{g}$ of trypsin or chymotrypsin and $2 \mathrm{mg}$ bacterial nitrogen per millilitre at a $p \mathrm{H}$ of 8.2 and 7.8 respectively, no activity was lost after $30 \mathrm{~min}$ at $37^{\circ} \mathrm{C}$. All organisms were tested twice as intact and twice as ruptured preparations. No activity was lost when the enzymes were added to the broths in which the organisms were grown. Trypsin-like or chymotrypsin-like enzymes could not be detected in any of the organisms studied, either whole, ruptured, or extracellularly in the broth.

RECOVERY OF ENZYMES A series of experiments was undertaken to test the recovery of enzymes instilled into the intestine. Patients on ileal drainage had their enzyme output determined over four consecutive days. A radioopaque polythene tube of $0.20 \mathrm{~cm}$ external diameter and $0.10 \mathrm{~cm}$ bore with a brass weight sutured to its tip was passed overnight into the second or third part of the duodenum. The position of the tube was checked radiologically. If satisfactory, a solution of bovine pancreatic trypsin and chymotrypsin cooled in ice was then administered by tube. This took place over four hours without interference with the patient's dietary regime. The position of the tube was checked radiologically before withdrawal. The first two subjects were given $100 \mathrm{mg}$ of both trypsin and chymotrypsin dissolved in $250 \mathrm{ml} 0 \cdot 15 \mathrm{M} \mathrm{NaCl}$. Patients 3 to 6 were given $200 \mathrm{mg}$ of both enzymes in $450 \mathrm{ml} 0 \cdot 15 \mathrm{M} \mathrm{NaCl}$ and patients 7 to 9 received the same quantity in $50 \mathrm{ml} 0 \cdot 15 \mathrm{M} \mathrm{NaCl}$. Patients 7 and 8 were in addition given neomycin sulphate in a dose of $2 \mathrm{~g}$, qid, during the basal and recovery periods (Table IV). In a further four subjects the experiment had to be abandoned after completion of the control collection because of difficulties in obtaining a satisfactory position of the tube. The ileal drainage material was collected for 48 hours after the start of enzyme administration and the output of enzymes in the homogenate determined.

TABLE IV

RECOVERY OF TRYPSIN AND CHYMOTRYPSIN FROM SUBJECTS ON ILEAL DRAINAGE AFTER INTRADUODENAL INSTILLATION ${ }^{1}$

\begin{tabular}{llll} 
Subject & Trypsin & Chymotrypsin & Protocol \\
\hline 1 & +105 & +90 & $100 \mathrm{mg}$ in $250 \mathrm{ml}$ \\
2 & +112 & +131 & $100 \mathrm{mg}$ in $250 \mathrm{ml}$ \\
3 & +28 & +58 & $200 \mathrm{mg}$ in $450 \mathrm{ml}$ \\
4 & -318 & +116 & $200 \mathrm{mg}$ in $450 \mathrm{ml}$ \\
5 & -30 & -2 & $200 \mathrm{mg}$ in $450 \mathrm{ml}$ \\
6 & -210 & +21 & $200 \mathrm{mg}$ in $450 \mathrm{ml}$ \\
7 & -28 & -48 & $200 \mathrm{mg}$ in $50 \mathrm{ml}$ \\
& & & Neomycin in test and \\
& & & control periods \\
8 & -27 & +233 & Neomycin in test and \\
& & & control periods \\
& & & $200 \mathrm{mg}$ in $50 \mathrm{ml}$
\end{tabular}

${ }^{1}$ Data give change in output for each subject in $\mathrm{mg}$ for the 48-hour period of test based upon four-day control period. All measurements on homogenate of ileal contents.

From the mean value obtained during the four-day basal period the enzyme recovery was calculated as the increment over the expected amount during the 48-hour collection period. In those patients given $100 \mathrm{mg}$ of each enzyme recovery was complete. The patients given $200 \mathrm{mg}$ of each enzyme failed to produce such a satisfactory recovery, and showed considerable variation. This variance could not be associated with any specific factors. Neither the volume in which the enzymes were administered nor prior sterilization of the gut with neomycin sulphate exercised any obvious effect upon recovery. Only two generalizations can be drawn from the data: that the output of trypsin was decreased instead of increased, and that the recovery of added chymotrypsin averaged $38 \%$.

MEASUREMENT OF ENZYME CONSTANTS Attempts were made to compare the identity of the enzymes of ileal fluid with those of pancreatic origin. Aliquots of a single sample of human pancreatic juice were available for this purpose. When this material was 


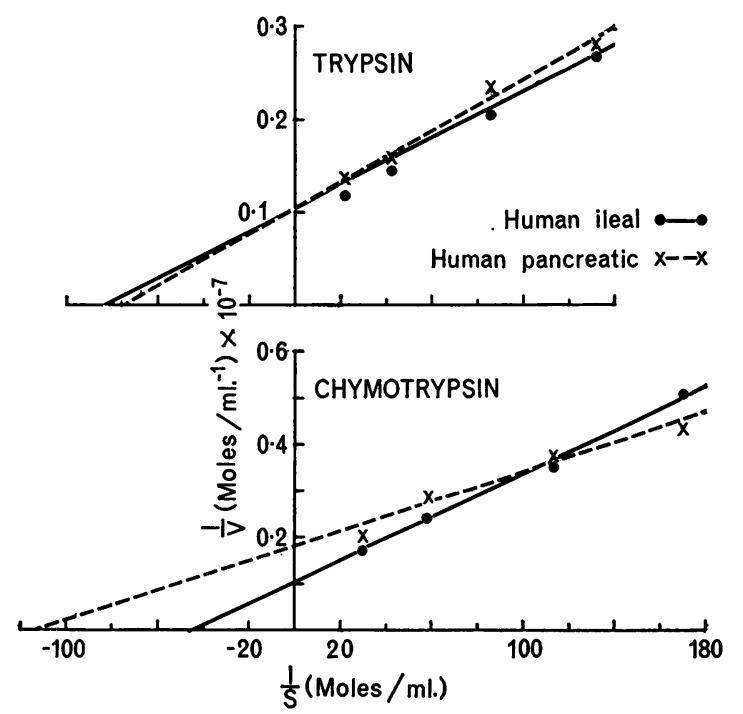

FIG. 1. Lineweaver-Burk plot of Michaelis equation for trypsin and chymotrypsin.

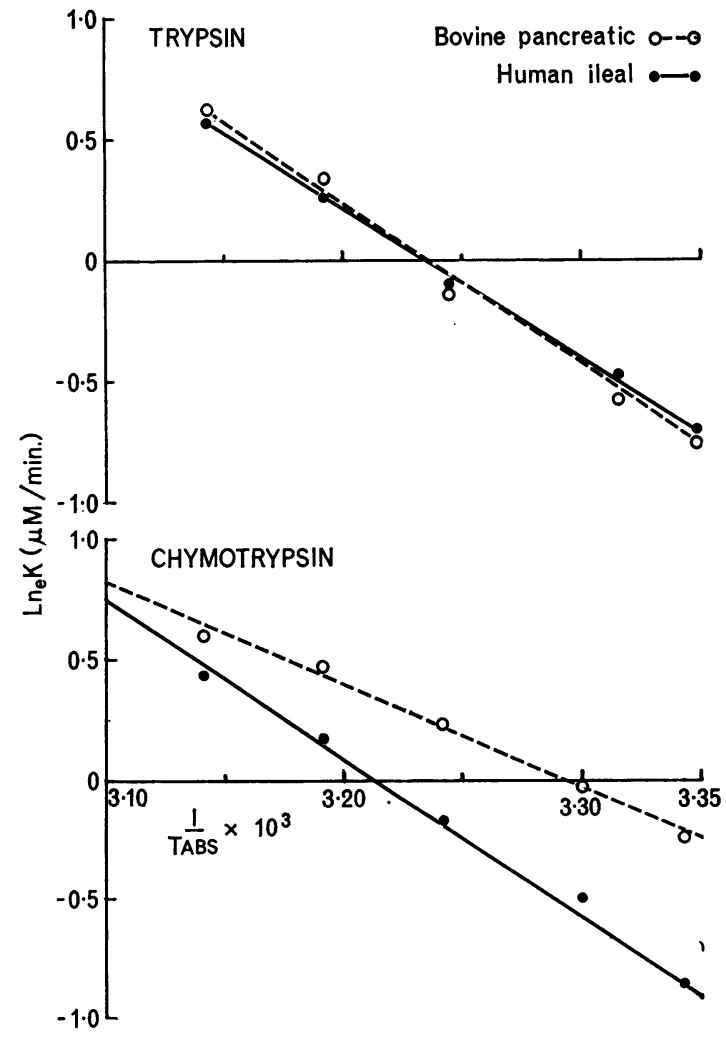

FIG. 2. Arrhenius plot showing relationship between temperature and velocity for trypsin and chymotrypsin. exhausted bovine pancreatic enzymes were used instead.

The relationship between substrate concentration and reaction velocity was studied, and the data used to calculate the Michaelis constant according to the reciprocal plot of Lineweaver and Burk (1934) as shown in Figure 1. The value for human pancreatic trypsin $\left(13.0 \times 10^{-3}\right)$ compared well with that of ileal fluid $\left(12.5 \times 10^{-3}\right)$, the differences being within the limits of experimental error. The value for human pancreatic chymotrypsin $\left(8.3 \times 10^{-3}\right)$ was substantially different from that of ileal fluid $\left(23.8 \times 10^{-3}\right)$.

The relationship between temperature and reaction velocity was studied in order to calculate the energy of activation for the enzymes according to the Arrhenius plot (Fig. 2). The values for bovine pancreatic and ileal fluid trypsin were 13,500 and 12,800 cals per mole respectively, a difference of this magnitude being within the limits of experimental error. The value for bovine pancreatic chymotrypsin ( 8,500 cals per mole) was substantially different from that of ileal fluid $(13,200$ cals per mole).

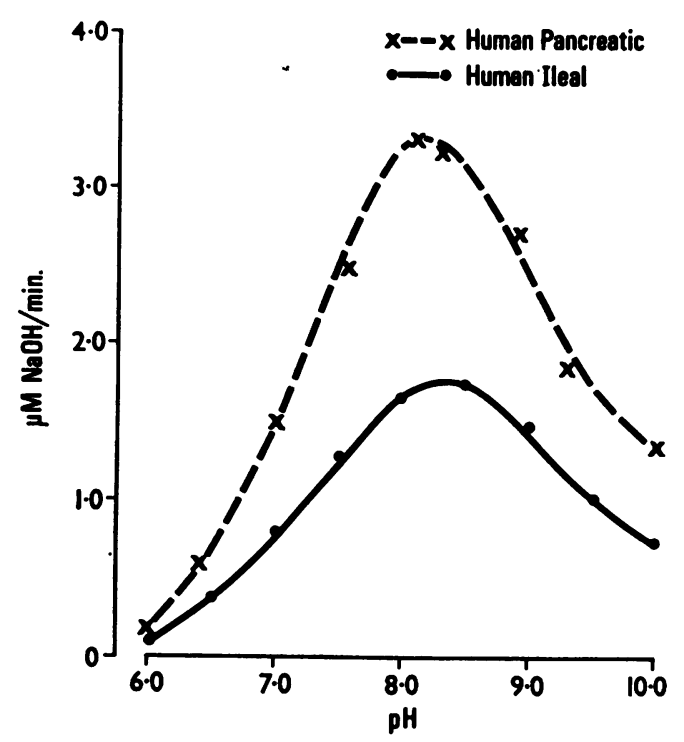

FIG. 3. The pH-activity curves for trypsin.

The $p \mathrm{H}$ activity curves were studied in the universal buffer system of Davies (1959). Excellent agreement was obtained for trypsin of pancreatic and ileal fluid (Fig. 3). Reproducible curves for chymotrypsin could not be obtained. Several experiments were conducted with pancreatic and ileal fluid, but spontaneous decomposition of the substrate at $p \mathrm{H}$ values outside the range 6.5 to 8.0 led 
to very high blanks and uncertainty concerning the possibility of subsidiary peaks. Three samples of ileal fluid showed the main peak of activity at three different $p \mathrm{H}$ values, $6.5 \quad 7.0$, and 9.0 compared with a value of $7 \cdot 5$ for pancreatic chymotrypsin.

\section{DISCUSSION}

The inactivation of pancreatic enzymes by human gastric juice agrees with previous studies on trypsin and lipase (Heizer, Cleaveland, and Iber, 1965). The stability of trypsin in acid and bile has already been rezorded (Elmslie, 1965). Our results show rapid inactivation of chymotrypsin by gastric juice, partial inactivation by acid, and stability in bile. The finding that the major part of trypsin and chymotrypsin is still active after six hours at $37^{\circ} \mathrm{C}$ is at variance with previous reports claiming rapid inactivation over periods as short as $30 \mathrm{~min}$ (Lundh, 1958; Wohlman, Kabacoff, and Avakian, 1962). Previous work involved intestinal juice obtained by intubation. This would exclude cell debris which, by binding of the enzymes at a site other than the active centre, contribute to the preservation of the enzymes in an active configuration by a form of particle stabilization (Goldberg et al, 1968a).

The autoincubation experiments give some indication of the likely contribution of bacterial and intestinal cell proteolysis to enzyme degradation. More direct experiments have shown these to be of little importance. Our failure to demonstrate any change in activity when the enzymes were incubated with preparations of fresh small intestinal epithelium is of considerable interest. Human small intestinal mucosa may be unique in being able to bind trypsin and chymotrypsin without inactivation, and contrasts with the mucosa of the colon which inactivates the enzymes and shows no capacity to bind them in the fresh state (Goldberg et al, 1968a). These observations may prove helpful in contributing to an understanding of the processes involved in protein digestion and cell protection.

The effect of neomycin on enzyme output is surprising in view of previous claims that sterilizing the gut in the rat (Borgström et al, 1959) and in man (Haverback et al, 1963) increases the faecal output of pancreatic enzymes. Neomycin in final concentrations up to $50 \mathrm{mg} / \mathrm{ml}$ had no effect upon the enzyme activity of ileal contents in vitro. The reduction in trypsin output which followed administration of the drug could be due to the following factors:

1 Removal of bacteria which produce trypsin-like enzymes, which is unlikely, since Grossman (1962) has shown that bacteria do not produce such enzymes in the dog, and we have been unable to detect trypsin or chymotrypsin activity in any strain examined so far.

2 Liberation of proteolytic enzymes from dead bacteria, which has been eliminated by direct measurement of proteolytic activity (Goldberg, McAllister, and Roy, 1968b).

3 Changes in the intestinal cell lining, which are known to occur as a consequence of neomycin therapy (Jacobson, Prior, and Faloon, 1960). It is conceivable that the altered epithelium has a greater avidity for trypsin.

4 Direct effect upon the pancreas: it is possible that small quantities of the drug following systemic absorption might have such an effect. This would add a further explanation for the malabsorption associated with the use of the drug (Jacobson, Chodos, and Faloon, 1960; Jacobson and Faloon, 1961). The fact that trypsin and chymotrypsin are not affected in parallel need not preclude a direct effect upon the pancreas, since recent dietary experiments have shown that the rates of synthesis of individual pancreatic enzymes respond differently, both in degree and in direction, to various stimuli (Snook, 1965; Reboud, Marchis-Mouren, Pasero, Cozzone, and Desnuelle, 1966). Evidence is available which points to a deficiency of lipase induced by neomycin (Rogers, Vloedman, Bloom, and Kalser, 1966). It has also been established in bacterial systems that neomycin causes amino-acid substitutions in peptide chains leading to impaired synthesis of certain enzymes (Gorini, 1966).

In view of our findings with neomycin, the attempts to characterize the enzymes in ileal fluid are relevant. These studies could not be carried out exclusively using human pancreatic enzymes. To that extent, a cautious interpretation of experiments with enzymes of bovine origin is indicated. It may be seen (Figs. 1 to 3 ) that the enzyme constants of ileal fluid trypsin agree with those for pancreatic trypsin, whereas differences with chymotrypsin are apparent. This latter anomaly may be explained by conversion of chymotrypsin to a variety of molecular forms during contact with high trypsin concentration in the course of intestinal transit (Desnuelle, 1960), and several peaks of chymotrypsin have been identified by Sephadex chromatography of rat intestinal contents (Snook and Meyer, 1964). The process of activation used for the human pancreatic juice in this work produces $\alpha$-chymotrypsin only (Rovery, Poilroux, Yoshida, and Desnuelle, 1957), and $\alpha$-chymotrypsin of bovine origin was used in other experiments. Thus the differences noted do not signify that ileal fluid chymotrypsin is not of pancreatic origin.

So far we have defined gastric juice and autodegradation as the main factors leading to loss of 
enzyme activity in the human small intestine. Since pepsin can only function at an acid $p \mathrm{H}$ it is unlikely that gastric juice would exercise an effect in the absence of regurgitation of intestinal contents. Assuming a transit time of four to six hours from the duodenum to the terminal ileum, an approximation that corresponds with data obtained using markers in our subjects, one might expect that at least $60 \%$ of trypsin and chymotrypsin would reach the terminal ileum intact. The results of the intubation experiments are therefore surprising.

It is difficult to reconcile the complete recovery obtained in two subjects when $100 \mathrm{mg}$ of each enzyme was administered with the poor recovery found in seven subjects given $200 \mathrm{mg}$. The daily output before administration of the enzyme appeared sufficiently consistent to allow application of these values for the calculation of enzyme recovery. We have been unable to find any factors such as faulty positioning of the tube or regurgitation into the stomach which might explain this poor recovery. In view of claims that pancreatic enzymes may be absorbed into the blood stream (Kabacoff, Wholman, Umhey, and Avakian, 1963), we have tested for this possibility in two patients by sampling blood at four hours and eight hours after the start of administration, but no increment over the zero time control could be detected in the trypsin or chymotrypsin activity of whole blood and serum.

This leaves a number of alternative explanations for the poor recoveries: (1) The bulk of the administered enzymes were destroyed. This requires dismissal of the results in the first two patients as due to chance. (2) Added enzymes are adsorbed to mucosal cells in situ. (3) The operation of a feedback mechanism controlling the level of intestinal enzymes. This suggestion has attractive implications. It ts conceivable that some factor which is stimulated by pancreatic enzymes operates to diminish pancreatic flow in a manner analogous to the inhibition of gastric acid by acid stimulation of the duodenum. The daily output of trypsin and chymotrypsin in these subjects averaged $208 \mathrm{mg}$ and $320 \mathrm{mg}$ respectively. Administration of $200 \mathrm{mg}$ would double the daily trypsin output, but since this was given over four hours there could be a 12-fold increase in enzyme concentration. It has been shown that feeding of trypsin inhibitor to the rat and chick results in pancreatic hypertrophy and increased enzyme production and secretion, especially of trypsin (Chernick, Lepkovsky, and Chaikoff, 1948; Lyman, 1957; Booth, Robbins, Ribelin, and De Eds, 1960; Haines and Lyman, 1961; Khayambashi and Lyman, 1966). The fact that this response is seen after a single feed of inhibitor (Lyman and Lepkovsky, 1957; Lyman, Wilcox, and Monsen,
1962) would fit in with the concept of a feedback mechanism linking the rate of pancreatic secretion with intestinal trypsin concentration inversely.

We have compared the output from our subjects with recent indirect estimates of pancreatic secretion. The consistently higher output of chymotrypsin accords with the fact that the human pancreas has a higher content of chymotrypsinogen than of trypsinogen (Figarella, 1966). Worning and Müllertz (1966) have reported the enzyme concentrations of human duodenal contents during stimulation by a test meal in healthy subjects. On the basis of a mean trypsin concentration which we estimate at 200 $\mu \mathrm{g} / \mathrm{ml}$ and a mean volume of $188 \mathrm{ml} / 90 \mathrm{~min}$, a theoretical daily output may be about $700 \mathrm{mg}$.

Petersen, Myren, and Foss (.1967) have studied the protein content of pancreatic juice. Applying their mean value of $100 \mathrm{mg} / 100 \mathrm{ml}$, and resting volume of $26 \mathrm{ml} / 20 \mathrm{~min}$ yields a figure of $1.9 \mathrm{~g}$ protein secreted daily by the human pancreas. Cook, Lennard-Jones, Sherif, and Wiggins (1967) have measured trypsin activity in duodenal aspirates from healthy subjects after stimulation by a test meal, and report a mean value of $5 \mathrm{~m}$-equiv/min during a two-hour period. We estimate this to represent an output of approximately $300 \mathrm{mg} /$ day. Although Cook et al (1967) state their recovery to vary between 15 and $25 \%$, the rates measured during their studies would represent maximal pancreatic output over short periods, much lower values being applicable to basal conditions.

Although we have been unable to reach a firm conclusion on the question that prompted these investigations, it is to be hoped that publication of the present data will stimulate further research in this field. There is an urgent need for reliable information on the daily enzyme output of the human pancreas. Studies on the recovery of labelled enzymes would also assist in circumventing the uncertainties of the present techniques.

\section{SUMMARY}

The fate of trypsin and chymotrypsin in the human small intestine has been studied using in-vitro methods to assess the interaction of gastrointestinal secretions and cells upon bovine pancreatic enzymes, and in-vivo methods to assess bacterial degradation and recovery of enzymes administered by intubation to subjects on ileal drainage under controlled dietary and metabolic conditions.

Gastric juice produced rapid loss of activity of both enzymes which was almost complete by two hours. Bile was without effect on either enzyme, but $0.1 \mathrm{~N} \mathrm{HCl}$ inactivated chymotrypsin by $38 \%$ after two hours. Autoincubation of homogenates of 
ileostomy material brought about a decrease of $37 \%$ in trypsin and $26 \%$ in chymotrypsin after six hours, but homogenates of ileal and jejunal epithelium were without effect on bovine pancreatic enzymes.

The output of trypsin from subjects on ileal drainage was significantly reduced by neomycin sulphate but chymotrypsin output was unaffected. Calculation of Michaelis constants, activation energy, and $p \mathrm{H}$ optima gave good agreement between trypsin of pancreatic and ileal sources, but discrepancies were noted with chymotrypsin. Added bovine pancreatic enzymes were completely recovered in two subjects given $100 \mathrm{mg}$ of each by duodenal intubation. When $200 \mathrm{mg}$ of each was given to seven subjects recovery of chymotrypsin averaged $38 \%$, and trypsin output appeared to be suppressed. Absorption of enzymes into the blood stream could not be detected in two subjects. These results raise the possibility that neomycin may alter pancreatic secretion and are compatible with feedback inhibition of the pancreas by intestinal trypsin. The relationship between pancreatic enzymes and ileal output requires direct study of pancreatic secretions.

We are indebted to Professor A. W. Kay for advice and guidance during this work.

\section{REFERENCES}

Booth, A. N., Robbins, D. J., Ribelin, W. E., and De Eds, F. (1960) Effect of raw soybean meal and amino acids on pancreatic hypertrophy in rats. Proc. Soc. exp. Biol. (N.Y.), 104, 681-683.

Borgström, B., Dahlqvist, A., Gustafsson, B. E., Lundh, G., and Malmquist, J. (1959). Trypsin, invertase and amylase content of feces of germfree rats. Ibid., 102, 154-155.

- _- Lundh, G., and Sjövall, J. (1957). Studies of intestinal digestion and absorption in the human. J. clin. Invest., 36, 1521-1536.

Chernick, S. S., Lepkovsky, S., and Chaikoff, I. L. (1948). A dietary factor regulating the enzyme content of the pancreas: changes induced in size and proteolytic activity of the chick pancreas by the ingestion of raw soybean meal. Amer. J. Physiol., 155, 33-41.

Cook, H. B., Lennard-Jones, J. E., Sherif, S. M., and Wiggins, H. S. (1967). Measurement of tryptic activity in intestinal juice as a diagnostic test of pancreatic disease. Gut, 8, 408-414.

Davies, M. T. (1959). A universal buffer solution for use in ultra-violet spectrophotometry. Analyst, 84, 248-251.

Desnuelle, P. (1960). Chymotrypsin. In The Enzymes, 2nd ed., edited by P. D. Boyer, H. Lardy, and K. Myrbäck, vol. 4, pp. 93-118. Academic Press, New York.

Elmslie, R. (1965). The effect of bile on the activation of trypsinogen and the activity of trypsin in pancreatic juice. Brit. J. Surg. $52,465-470$.

Figarella, C. (1966). Composition et stabilité de l'équipement enzymatique du pancréas de l'homme et de divers animaux. Bull. Soc. Chim. biol. (Paris), 48, 97-115.

Goldberg, D. M., Campbell, R., and Roy, A. D. (1968a). Binding of trypsin and chymotrypsin by human intestinal mucosa. Biochim. biophys. Acta (Amst.). 671, 613-615.

- McAllister, R. A., and Roy, A. D. (1967). The proteolytic activity of human intestinal contents. Proc. Ass. clin. Biochem. 4, 202-205.

Scand. J. Gastroent

Gorini, L. (1966). Antibiotics and the genetic code. Sci. Amer. 214, no. $4,102-109$.
Grossman, M. I. (1962). Fecal enzymes of dogs with pancreatic exclusion. Proc. Soc. exp. Biol. (N.Y.), 110, 41-42.

Haines, P. C., and Lyman, R. L. (1961). Relationship of pancreatic enzyme secretion to growth inhibition in rats fed soybean trypsin inhibitor. $J$. Nutr., 74, 445-452.

Haverback, B. J., Dyce, B., Bundy, H., and Edmondson, H. A. (1960). Trypsin, trypsinogen and trypsin inhibitor in human pancreatic juice; mechanism for pancreatitis associated with hyperparathyroidism. Amer. J. Med., 29, 424-433.

,-- , Gutentag, P. J., and Montgomery, D. W. (1963). Measurement of trypsin and chymotrypsin in stool. A diagnostic test for pancreatic exocrine insufficiency. Gastroenterology, 44, 588-597.

Heizer, W. D., Cleaveland, C. R., and Iber, F. L. (1965). Gastric inactivation of pancreatic supplements. Bull. Johns Hopk. Hosp., 116, 261-270.

Jacobson, E. D., Chodos, R. B., and Faloon, W. W. (1960). An experimental malabsorption syndrome induced by neomycin. Amer. J. Med., 28, 524-533.

, and Faloon, W. W. (1961). Malabsorptive effects of neomycin in commonly used doses. J. Amer. med. Ass., 175, 187-190.

- Prior, J. T., and Faloon, W. W. (1960). Malabsorptive syndrome induced by neomycin: morphologic alterations in the jejunal mucosa. J. Lab. clin. Med., 56, 245-250.

Kabacoff, B. L., Wohlman, A., Umhey, M., and Avakian, S. (1963) Absorption of chymotrypsin from the intestinal tract. Nature (Lond.), 199, 815.

Khayambashi, H., and Lyman, R. L. (1966). Growth depression and pancreatic and intestinal changes in rats force-fed amino acid diets containing soybean trypsin inhibitor. J. Nutr., 89, 455-464.

Lineweaver, H., and Burk, D. (1934). The determination of enzyme dissociation constants. J. Amer. chem. Soc., 56, 658-666.

Lundh, G. (1957). Determination of trypsin and chymotrypsin in human intestinal content. Scand. J. clin. Lab. Invest., 9 , 229-232.

(1958). Intestinal digestion and absorption after gastrectomy. Acta. chir. scand., suppl. 231.

Lyman, R. L. (1957). The effect of raw soybean meal and trypsin inhibitor diets on the intestinal and pancreatic nitrogen in the rat. J. Nutr., 62, 285-294.

_- and Lepkovsky, S. (1957). The effect of raw soybean meal and trypsin inhibitor diets on pancreatic enzyme secretion in the rat. Ibid., 62, 269-284.

-, Wilcox, S. S., and Monsen, E. R. (1962). Pancreatic enzyme secretion produced in the rat by trypsin inhibitors. Amer. $J$ Physiol., 202, 1077-1082.

Pelot, D., and Grossman, M. I. (1962). Distribution and fate of pancreatic enzymes in small intestine of the rat. Ibid., 202 , 285-288.

Petersen, H., Myren, J., and Foss, O. P. (1967). Total nitrogen content of human duodenal juice before and after intravenous injection of secretin. Scand. J. Gastroent., 2, 1-6.

Prunty, F. T. G., McSwiney, R. R., and Hawkins, J. B. (1959) A Laboratory Manual of Chemical Pathology, p. 165. Pergamon Press, Oxford.

Reboud, J. P., Marchis-Mouren, G., Pasero, L., Cozzone, A., and Desnuelle, P. (1966). Adaptation of rate of biosynthesis of pancreatic amylase and chymotrypsinogen to starch rich or protein-rich diets. Biochim. biophys. Acta. (Amst.), 117, 351-367.

Rogers, A. I., Vloedman, D. A., Bloom, E. C., and Kalser, M. H (1966). Neomycin-induced steatorrhea. A preliminary report on the in vivo hydrolysis of a long-chain unsaturated fat. J. Amer. med. Ass., 197, 185-190.

Rovery, M., Poilroux, M., Yoshida, A., and Desnuelle, P. (1957). Sur la dégradation du chymotrypsinogene par la chymotrypsine. Biochim. biophys. Acta. (Amst.), 23, 608-620.

Roy, A. D., Campbell, R., and Goldberg, D. M. (1967). Effect of diet on the trypsin and chymotrypsin output in the stools of patients with an ileostomy. Gastroenterology, 53, 584-589.

Snook, J. T. (1965). Dietary regulation of pancreatic enzyme synthesis. secretion and inactivation in the rat. $J$. Nutr., 87, 297-305.

proteolytic enzymes. Ibid., 83, 94-102.

Wohlman, A., Kabacoff, B. L., and Avakian, S. (1962). Comparative stability of trypsin and chymotrypsin in intestinal juice. Proc. Soc. exp. Biol. (N.Y.), 109, 26-28.

Worning, H., and Müllertz, S. (1966). $p H$ and pancreatic enzymes in the human duodenum during digestion of a standard meal. Scand. J. Gastroent., 1, 268-283. 